\title{
Ignalinos AE 1-ojo bloko vandens valymo ir aušinimo sistemos radiologinio užterštumo tyrimas
}

\author{
Gintautas Poškas ${ }^{1,2}$, \\ Rimantas Zujus', \\ Gintautas Miliauskas ${ }^{2}$ \\ ${ }^{1}$ Lietuvos energetikos institutas, \\ Branduolines inžinerijos \\ problemy laboratorija, \\ Breslaujos g. 3, LT-44403 Kaunas \\ El.paštas: g.poskas@gmail.com \\ ${ }^{2}$ Kauno technologijos universitetas, \\ Šilumos ir atomo energetikos katedra, \\ K. Donelaičio g. 20, \\ LT-44239 Kaunas \\ El.paštas: gintautas.miliauskas@ktu.lt
}

\begin{abstract}
Straipsnyje pateikiami Ignalinos AE 1-ojo bloko vandens valymo ir aušinimo sistemos (VVAS) įrangos užterštumo modeliavimo rezultatai. Modeliuota modifikuotu programų paketu LLWAA-DECOM (Tractebel Energy Engineering, Belgija) įvertinant informaciją apie VVAS komponentų charakteristikas, kontūruose tekančio vandens parametrus, sistemos darbo režimus ir kt. Modeliavimu gauti rezultatai apie VVAS posistemių ir komponentų nuosėdų bendrą aktyvumą ir nuosėdų nuklidinę sudètị reaktoriaus galutinio sustabdymo metu bei labiausiai užterštų komponentų nuosėdų aktyvumo kitimą ir jų skleidžiamos suminès dozès galią po reaktoriaus galutinio sustabdymo.

Nustatyta, kad VVAS posistemių bei jų komponentų užterštumas yra labai skirtingas. Išvalyto vandens posistemès labiausiai užteršto ir mažiausiai užteršto komponentų aktyvumas sudaro 28,33 ir $0,86 \%$, palyginti su labiausiai užteršto nevalyto vandens posistemès komponento aktyvumu, o papildomo vandens aušinimo posistemès komponentų aktyvumas yra nežymus.
\end{abstract}

Raktažodžiai: Ignalinos AE, vandens valymo ir aušinimo sistema, paviršių užterštumas, dozès galia

\section{IVADAS}

Ignalinos atominė elektrinè (IAE) $2009 \mathrm{~m}$. gruodžio $31 \mathrm{~d}$. visiškai nutraukè elektros energijos gamybą. Tuomet IAE pagrindine veikla tapo jos eksploatacijos nutraukimo procesas. Šio proceso optimaliai eigai užtikrinti būtini bent preliminarūs duomenys apie eksploatavimo nutraukimo metu susidarysiančių radioaktyviụjų atliekų kiekį, radioaktyvumo lygi, nuklidinę sudèti ir kt. Eksploatuojant atominę elektrinę užteršiamas ne tik reaktorius, bet ir priverstinès cirkuliacijos kontūras (PCK) bei PCK posistemès, tarp ju ir vandens valymo bei aušinimo sistema (VVAS). Užteršimą radioaktyviomis dalelèmis lemia aušinimo skysčio (Ignalinos AE atveju, vandens) cirkuliacija šiose sistemose. Pats vanduo yra užteršiamas dèl korozijos ir aktyvacijos procesų, taip pat galimų kuro apvalkalų defektų. Esant priverstinei vandens cirkuliacijai minètose $\mathrm{AE}$ sistemose vyksta radioaktyviụjų dalelių nusėdimas ant jų komponentų vidinių sienučių paviršių.

VVAS teka PCK vanduo, kuris aukštoje temperatūroje yra geras korozijos reakcijos katalizatorius ir, apiplaudamas metalinius komponentus, skatina jų korozijos procesus. Korozijos intensyvumas reaktoriaus įrangos komponentuose priklauso nuo daugelio veiksnių: temperatūros, komponentų sudèties bei eksploatavimo trukmès, šilumnešio tekèjimo režimo ir daugelio kitų. Korozijos produktų susiformavimo procesas ir pernašos mechanizmai apžvelgti [1-4]. 
PCK vanduo aktyvacijos produktais užteršiamas keletu būdų [5]. Šilumnešis perneša taršos daleles ị reaktoriaus aktyviąją zoną. Čia jos sudaro nuosedas ant aktyvioje zonoje esančios įrangos paviršių ir yra aktyvuojamos veikiant dideliems neutronų srautams. Šios aktyvuotos taršos dalelès dèl erozijos patenka í cirkuliuojantị šilumneši, yra pernešamos PCK ir nusèda ant ịrangos, esančios už reaktoriaus aktyviosios zonos, paviršių. Taršos dalelès gali ir nenusėsti ant ịrangos sienučiu reaktoriaus aktyviojoje zonoje - jos aktyvuojamos cirkuliacijos per aktyviąją zoną metu ir taip pat formuoja nuosèdų sluoksni ant ịrangos, esančios už aktyviosios zonos ribų, paviršių. Kitas aktyvacijos produktų PCK šaltinis yra aktyviojoje zonoje esančios ịrangos medžiagos aktyvacija ir dèl korozijos bei erozijos í vandeni patenkantys aktyvacijos produktai. Sienučiu radioaktyvus užterštumas yra paviršinis, nes aktyvuotos dalelès nusèda ant ịrangos paviršiaus.

Esant kuro kanalu defektams, branduoliniame kure esantys skilimo produktai gali migruoti ir per pažeistas kuro apvalkalų vietas patekti ị PCK cirkuliuojantị šilumneši. Papildomai skilimo produktai yra generuojami skylant „paklydusiam“ uranui (angl. „tramp“ uranium), kurio dalelès yra kuro komponentų apvalkalu išorèje (užteršiami apdirbant kurą). Eksploatacijos metu šilumnešis gali būti užteršiamas šiomis dalelèmis [7]. „Paklydusio“ urano skilimo produktų spektras analogiškas skilimo produktų spektrui branduoliniame kure.

Šiame straipsnyje pateikiami modeliavimo rezultatai apie Ignalinos AE 1-ojo bloko VVAS įrangos bendrą aktyvumą ir nuosėdų nuklidinę sudètį bei labiausiai užterštų komponentų nuosèdų aktyvumo kitimą ir jų skleidžiamos suminès dozès galią po reaktoriaus galutinio sustabdymo.

\section{VANDENS VALYMO IR AUŠINIMO SISTEMA (VVAS)}

VVAS palaiko priverstinès cirkuliacijos kontūro vandens kokybę, valydama PCK vandeni nuo korozijos produktu ir tirpiu drusku bei taip kontroliuodama PCK vandens radioaktyvumo lygi. Taip pat VVAS tiekia vandeni reaktoriui stabdymo arba avariniu atvejais, plaunant PCK sistemą reaktoriaus techninio aptarnavimo metu bei kaupia reaktoriui paleisti reikalinga $50{ }^{\circ} \mathrm{C}$ temperatūros vandeni rezervuare [6]. Pagal vandens taršą VVAS galima suskirstyti i tris posistemes: nevalyto vandens, išvalyto vandens ir papildomo aušinimo. Supaprastinta VVAS technologinė schema pateikta 1 pav.

VVAS susideda iš vamzdžiu atšaku nuo būgnų-separatoriu ir slèginiu kolektoriu $(1,5)$, dviejų mechaninių filtru prieš siurblius (2), dviejų siurbliu (4), dviejų regeneratoriu po šešis korpusus (7), dviejų papildomų aušintuvų blokų (26), penkių mechaninių perlitinių filtrų (14), dviejų jonų mainų filtrų (17), vieno filtro-gaudyklès (19). Pagrindiniai VVAS komponentai išvardinti lenteleje.

Reaktoriaus normalios eksploatacijos metu dalis PCK vandens iš slèginių kolektorių (5) yra tiekiama ị VVAS ir patenka ị regeneratorius $(7,8)$, kuriuose yra atvesinamas

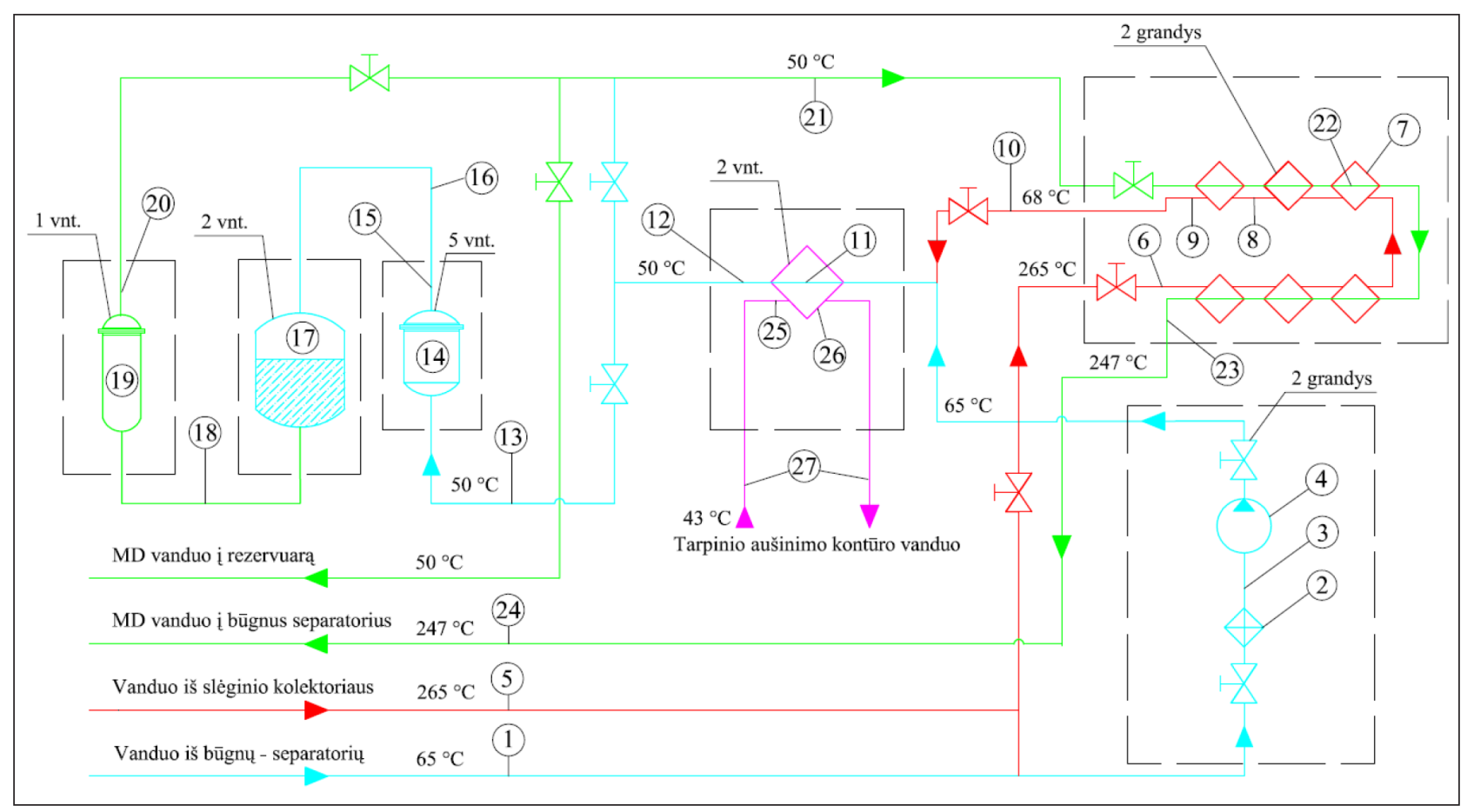

1 pav. Supaprastinta VVAS schema: 1-17 nevalyto vandens posistemè; 18-24 išvalyto vandens posistemè; 25-27 papildomo aušinimo posistemè 
Lentelè. Pagrindiniai VVAS komponentai

\begin{tabular}{|c|c|c|}
\hline \multicolumn{3}{|c|}{ Nevalyto vandens posistemè (NV-1) } \\
\hline Nr. & Komponento pavadinimas & Žymèjimas \\
\hline 1. & Vamzdžiai iš būgno-separatoriaus i VVAS siurblius & VVAS-1 \\
\hline 2. & Vamzdžiai iš slèginių kolektorių i VVAS siurblius & VVAS-1 \\
\hline 3. & Mechaniniai filtrai prieš siurblius (korpusas) & VVAS-3 \\
\hline 4. & Lygiagretūs vamzdžiai i i ir iš VVAS siurblių & VVAS-4 \\
\hline 5. & VVAS siurbliai CNR-500-115 (korpusas) & VVAS-5 \\
\hline 6. & lèjimo vamzdžiai iš siurblių i regeneratorius & VVAS-6 \\
\hline 7. & Regeneratorius (korpuso vidinis paviršius) & VVAS-7 \\
\hline 8. & Regeneratorius (vamzdžių išorinis paviršius) & VVAS-8 \\
\hline 9. & Vamzdžiai iš regeneratorių i papildomą aušintuvą & VVAS-9 \\
\hline 10. & Vamzdis iš regeneratoriaus i papildomą aušintuvą & VVAS-10 \\
\hline 11. & Papildomas aušintuvas (vamzdžių vidinis paviršius) & VVAS-11 \\
\hline 12. & Vamzdžiai iš papildomo aušintuvo i vandens valymo įrangą & VVAS-12 \\
\hline 13. & Vamzdžiai iš papildomo aušintuvo į mechaninius perlitinius filtrus & VVAS-13 \\
\hline 14. & Mechaninis perlitinis filtras (korpusas) & VVAS-14 \\
\hline 15. & Mechaniniai perlitinių filtrų vamzdžiai & VVAS-15 \\
\hline 16. & Vamzdis i jonų mainų filtrus & VVAS-16 \\
\hline 17. & Jonų mainų filtras (korpusas) & VVAS-17 \\
\hline \multicolumn{3}{|c|}{ Išvalyto vandens posistemè (NV-2) } \\
\hline 18. & Vamzdis tarp jonų mainų ir filtro-gaudyklès & VVAS-18 \\
\hline 19. & Filtras-gaudyklè (korpusas) & VVAS-19 \\
\hline 20. & Vamzdis iš filtro-gaudyklès ị regeneratorių & VVAS-20 \\
\hline 21. & Vamzdis ị regeneratorius & VVAS-21 \\
\hline 22. & Regeneratorius (vamzdžių vidinis paviršius) & VVAS-22 \\
\hline 23. & Grižžtančio į būgną-separatorių vandens vamzdžiai & VVAS-23 \\
\hline 24. & Grįžtančio į būgną-separatorių vandens vamzdis & VVAS-24 \\
\hline \multicolumn{3}{|c|}{ Papildomo vandens aušinimo posistemė (NV-3) } \\
\hline 25. & Papildomas aušintuvas (vamzdžių išorinis paviršius) & VVAS-25 \\
\hline 26. & Papildomas aušintuvas (korpusas) & VVAS-26 \\
\hline 27. & Tarpinio kontūro vandens vamzdžiai ị ir iš papildomo aušintuvo & VVAS-27 \\
\hline
\end{tabular}

grị̌tančio išvalyto vandens srauto nuo $265^{\circ} \mathrm{C}$ iki $68^{\circ} \mathrm{C}$ temperatūros. Jonų mainų filtrų darbinè temperatūra yra iki $60{ }^{\circ} \mathrm{C}$, todèl $68{ }^{\circ} \mathrm{C}$ temperatūros vanduo papildomo aušinimo posistemèje $(25,26,27)$ yra papildomai aušinamas iki $50{ }^{\circ} \mathrm{C}$. Toliau vanduo vamzdžiais $(13,15)$ patenka i mechaninius perlitinius filtrus (14), kuriuose pašalinami korozijos produktai. Jonų mainų filtruose (17) iš vandens pašalinamos tirpios druskos ir radioaktyvaus skilimo produktai. Išvalytas vanduo vamzdžiu (21) vèl tiekiamas ị regeneratorius $(7,8)$. Čia jis pašildomas iki $247{ }^{\circ} \mathrm{C}$ temperatūros iš slèginių kolektorių atitekančiu vandeniu. Po to vamzdžiu (24) patenka ì būgnus-separatorius.

\section{UŽTERŠTUMO IৃVERTINIMO METODIKA}

Modeliuojant reaktoriaus sistemu radioaktyvuji užterštumą reikia įvertinti daugybę sudètingų taršos dalelių susiformavimo, jų pernešimo bei atpalaidavimo procesų ir atsižvelgti i jų tarpusavio sąveiką. Atskirų pernašos uždavinių detaliais vertinimo atvejais naudojami sudètingi matematiniai modeliai ir daug skaičiavimo resursų rei- kalaujantys jų skaitinio sprendimo algoritmai. Todèl vertinant radioaktyvųji užterštumą reaktorių sistemose yra daromi supaprastinimai, t. y. naudojami empiriniai ir pusiau empiriniai modeliai ir programos (PACTOLE [9], CRUDTRAN [9], ACE-II [10] ir kt.). Paprastai šie ir panašūs modeliai, programos yra specialiai pritaikomi konkrečiam reaktoriaus tipui [11].

Modeliuojant VVAS įrangos radioaktyvųji užterštumą buvo naudojamas programų paketas LLWAA-DECOM (Tractebel Energy Engineering, Belgija) [12]. Atliekant vertinimą šiuo paketu reikalinga informacija apie:

- sistemos darbo charakteristikas (darbo ciklų skaičių, darbo ciklo trukmę);

- cirkuliuojančio vandens parametrus (vandens pH, temperatūrą, vidutini greití, tūrinị aktyvumą);

- taršos dalelių charakteristikas (tankį, skersmení, tirpumą);

- sistemos komponentur konstrukcinius parametrus (konstrukcines medžiagas, komponento geometrinius matmenis, sienučių šiurkštumą, kt.) ir pan.

Ant sistemos komponento sienutės esančių nuklidų aktyvumo kitimas aprašomas lygtimi (1)[12]: 


$$
\frac{d W_{i}}{d t}=K_{d} * C v_{i} *\left(1-f r s p r_{i}\right)-W_{i} *\left(K_{r}+\lambda_{i}\right)
$$

čia: $w_{i}-i$-ojo nuklido, esančio ant sienutès, paviršinis aktyvumas, $\mathrm{Bq} / \mathrm{m}^{2} ; K_{d}$ - dalelių nusèdimo greitis, $\mathrm{m} / \mathrm{s}$; $C v_{i}$ - tūrinis i-ojo nuklido aktyvumas sraute, $\mathrm{Bq} / \mathrm{m}^{3}$; $f_{r s p r}$ - i-ojo nuklido tirpioji dalis cirkuliuojančiame agente; $K_{r}$ - dalelių atpalaidavimo koeficientas, $\mathrm{s}^{-1} ; \lambda_{i}-i$-ojo nuklido skilimo konstanta, $\mathrm{s}^{-1} ; t$ - laikas, $\mathrm{s}$. Nusèdimo ir atpalaidavimo koeficientai $\left(K_{d}, K_{r}\right)$ priklauso nuo srauto judèjimo charakteristiku (tekèjimo greičio, temperatūros, Reinoldso skaičiaus ir kt.), sistemos įrangos charakteristiku (geometrijos, vidinių sienučių šiurkštumo, trinties koeficiento) bei radioaktyviụjų dalelių charakteristikų (dalelių tankio sraute, skersmens).

Skaitinio eksperimento eigoje kiekvienam VVAS komponentui, pasinaudojant duomenimis apie šilumnešio nuklidinę sudètį ir nuklidų aktyvumus, nustatytas nuosèdose esančių nuklidų aktyvumas ir jų skleidžiamos bendros dozès galia ant komponento išorinio paviršiaus.

\section{REZULTATAI}

VVAS komponentų užterštumo modeliavimo rezultatų analizè parodè, kad VVAS nevalyto vandens posistemejje labiausiai užteršti komponentai yra: vamzdžiai iš slèginių kolektoriu i $\mathfrak{i}$ VVAS siurblius (VVAS-5) ir iejeimo vamzdžiai iš siurblių i r regeneratorius (VVAS-6) (2 pav.). VVAS išvalyto vandens posistemėje labiausiai užteršti komponentai: regeneratoriaus vamzdžių vidinis paviršius (VVAS-22) ir grịžtančiu i būgną-separatorių vandens vamzdžiai (VVAS23, VVAS-24) (3 pav.). VVAS papildomo vandens aušinimo posistemèje labiausiai užterštas komponentas yra papildomo aušintuvo vamzdžių išoriniai paviršiai (VVAS-27) (4 pav.).

5 pav. matyti, kad VVAS posistemių užterštumas yra labai skirtingas. Labiausiai užteršta yra nevalyto vandens posistemè (NV-1), tačiau ir jos komponentai yra užteršti labai netolygiai. Mažiausiai užteršto (NV-1) komponento aktyvumas yra tik 1,42\%, palyginti su labiausiai užteršto

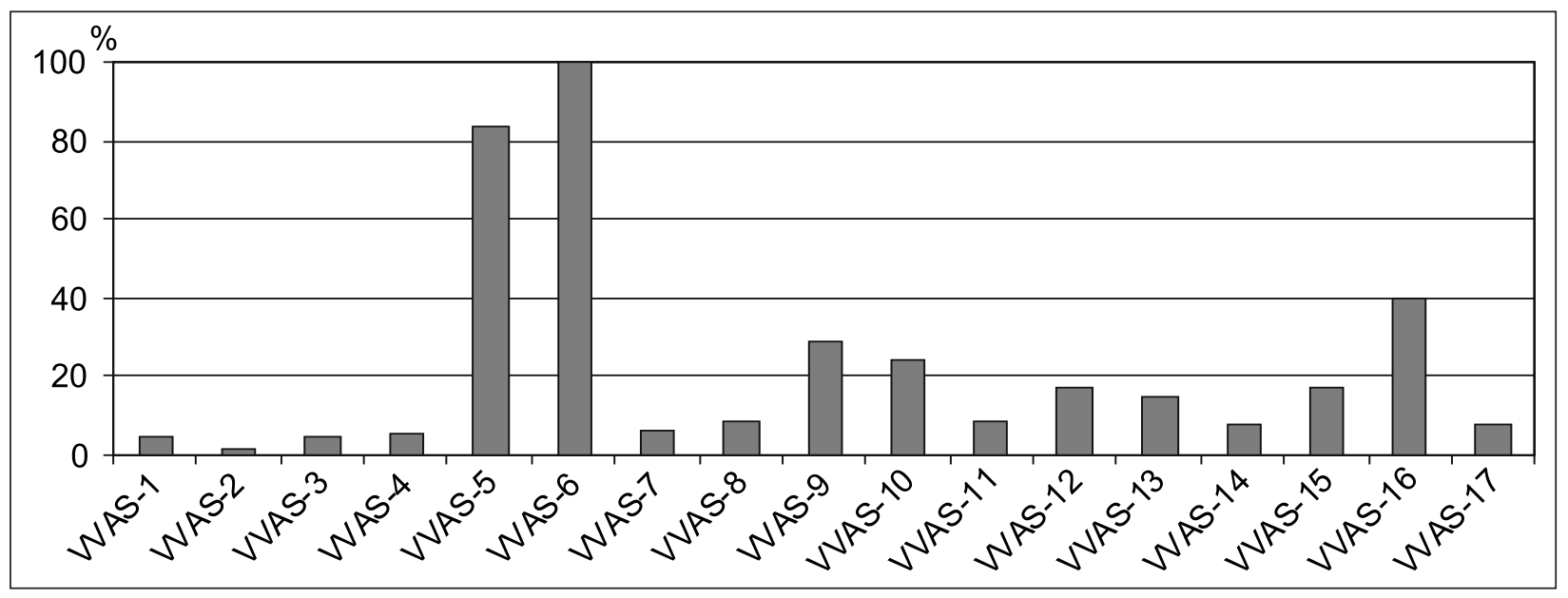

2 pav. VVAS nevalyto vandens posistemės komponentų santykinis aktyvumas (VVAS-i/VVAS-6)

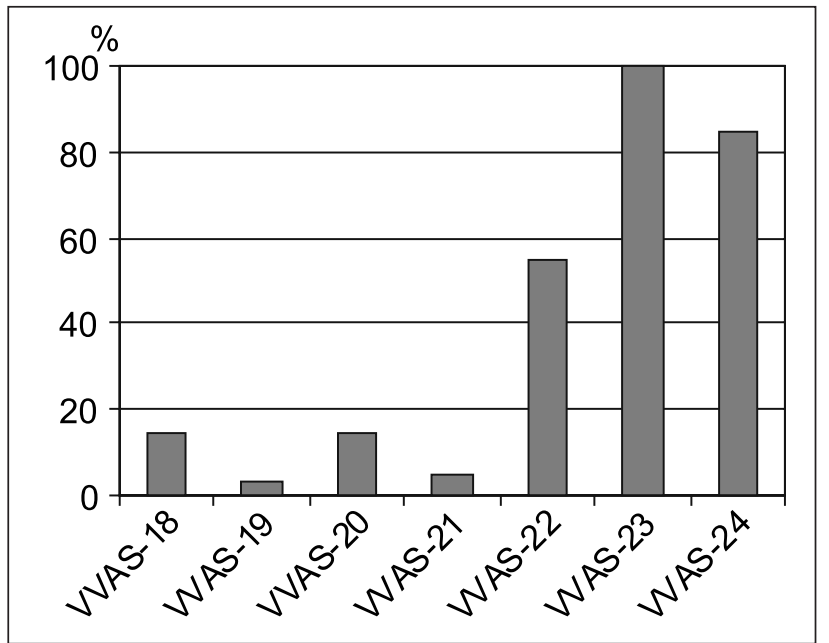

3 pav. VVAS išvalyto vandens posistemės komponentų santykinis aktyvumas (VVAS-i/VVAS-23)

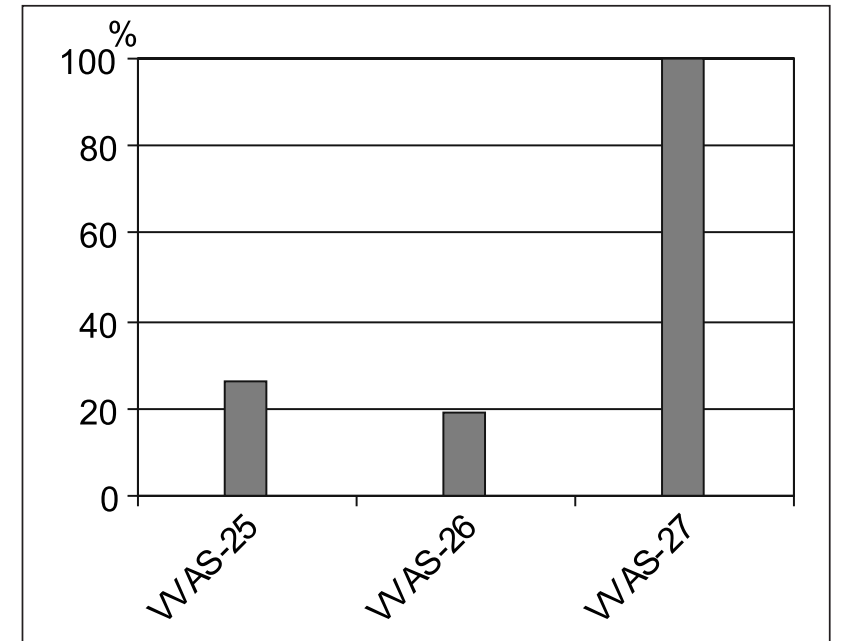

4 pav. VVAS papildomo vandens aušinimo posistemès komponentų santykinis aktyvumas (VVAS-i/VVAS-27) 


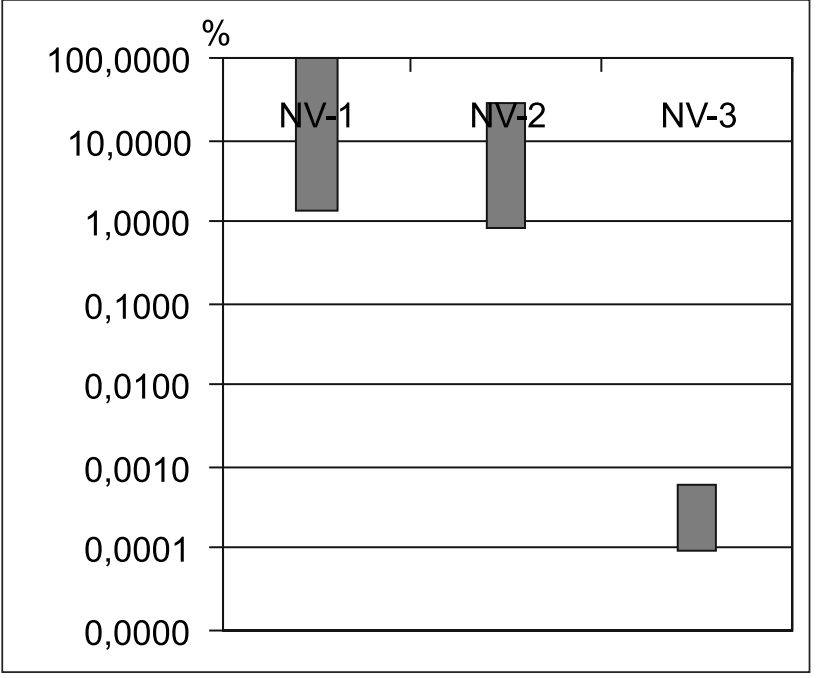

5 pav. VVAS posistemių komponentų aktyvumo pasiskirstymas (žr. pažymëjimus 1 lentelèje)

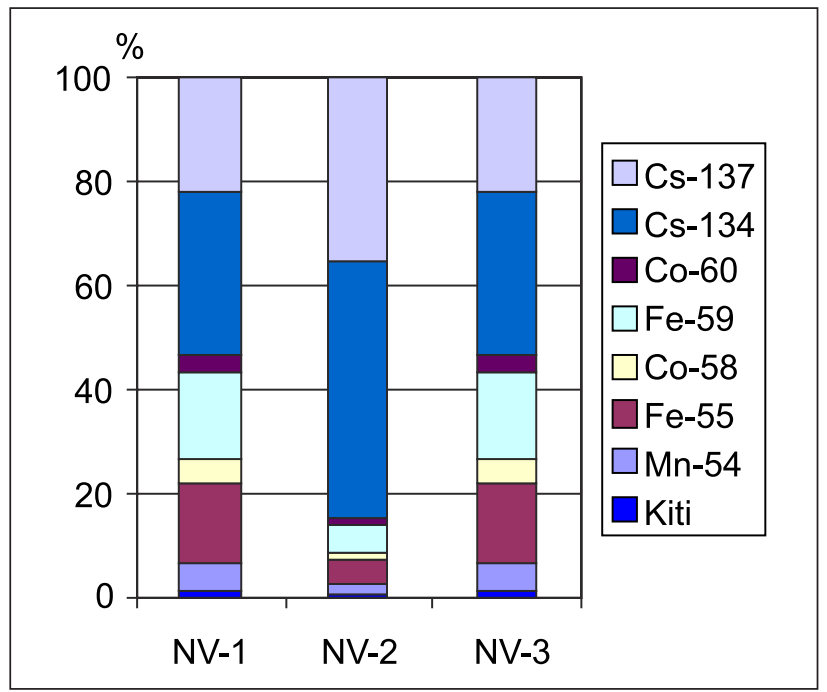

6 pav. VVAS posistemių vandens nuklidinè sudètis (kiti <1\%) komponento aktyvumu. Išvalyto vandens posistemès (NV-2) labiausiai užterštas ir mažiausiai užterštas komponentai sudaro atitinkamai 28,33 ir 0,86 \% aktyvumo, palyginti su labiausiai užteršto NV-1 komponento aktyvumu. Tuo tarpu papildomo vandens aušinimo posistemès (NV-3) komponento aktyvumas tesudaro 1/10000 procento dali, palyginti su labiausiai užteršto NV-1 komponento aktyvumu. NV-1 posistemès komponentų didesni aktyvumą lemia tai, kad jos komponentai yra prieš vandens valymo irenginius. Kaip parodyta, NV-1 posistemès komponentų 5 ir 6 užterštumas labai skiriasi nuo kitų NV-1 komponentų. Pagrindinè priežastis, kad šie komponentai yra prieš šilumokaitị, ir jais teka aukštos temperatūros vanduo. Po valymo įrenginių patenkantis vanduo ị NV-2 posistemę jos komponentus užteršia mažiau, tai lemia mažesni jos komponentų aktyvumą. NV-3 posistemės mažo aktyvumo priežastis, kad jos vanduo tiesiogiai nesimaišo su NV-1 ir NV-2 vandeniu. Kai kurių komponentų (pvz., 7 ir 22 arba 11 ir 26), esančių šilumokaityje, vidinių ir išorinių paviršių aktyvumas labai skiriasi, nes vienas paviršius apiplaunamos užteršto vandens, o kitas išvalyto arba neužteršto vandens.

Kiekvienoje VVAS posistemèje cirkuliuoja nevienodo užterštumo ir nuklidinès sudėties vanduo (6 pav.). Vandens užteršimą daugiausia lemia Cs-134 (NV-1 ir NV-3 31 \%; NV-2 50 \% bendro užterštumo) ir Cs-137 (NV-1 ir NV-3 22 \%; NV-2 35 \% bendro užterštumo) nuklidai.

Nuosèdose dominuojantis nuklidas yra Fe-55: NV-1 posistemejje 56- 59 \% bendro užterštumo (7 pav.); NV-2 posistemèje $\sim 55-\sim 56 \%$ bendro užterštumo ( 8 pav.); NV-3 posistemèje $\sim 58 \%$ bendro užterštumo ( 9 pav.). Vandenyje Fe-55 sudaro tiktai 5- 16 \% bendro užterštumo. Toks nuklidu pasiskirstymas nuosèdose priklauso nuo nuklidų koncentracijos ir jų tirpumo vandenyje. Iš vandens i nuosèdas pereiti gali tik vandenyje neištirpusi nuklido

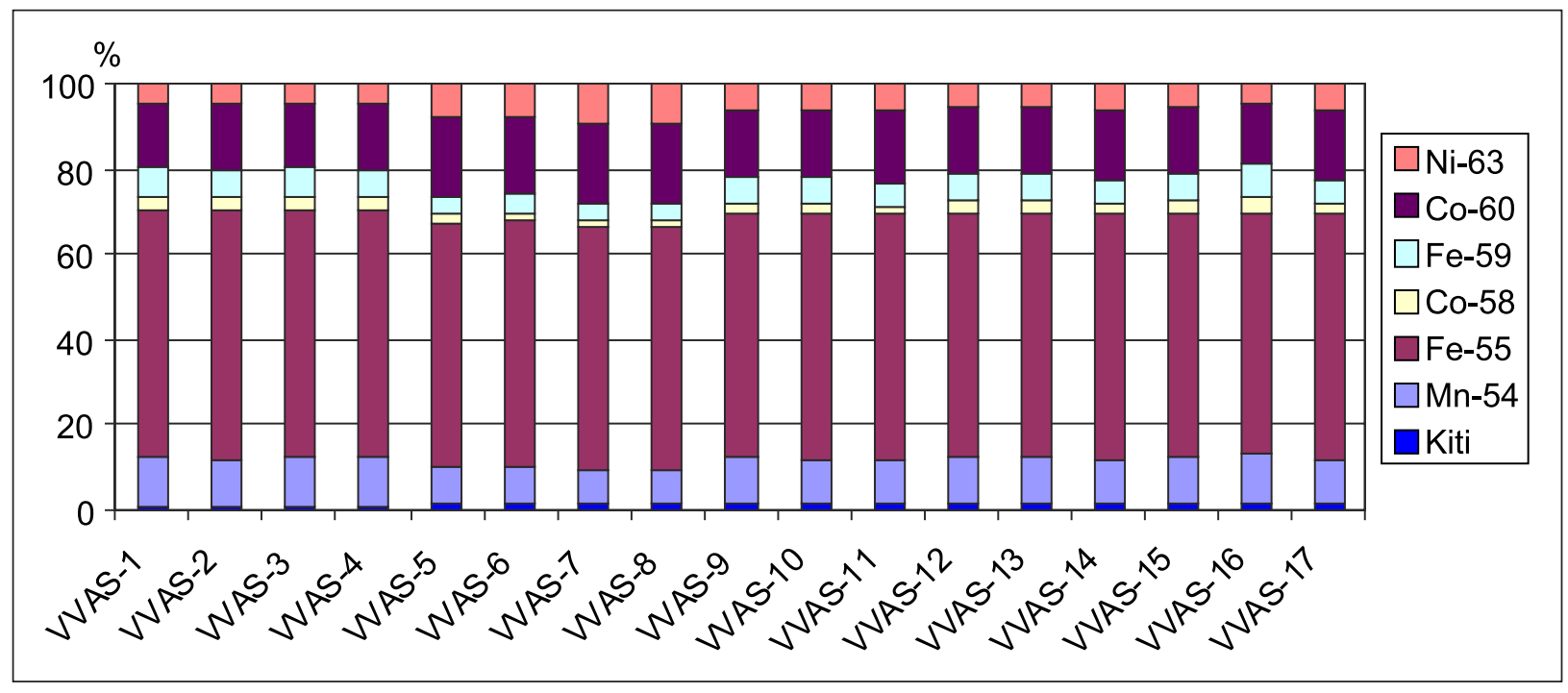

7 pav. VVAS nevalyto vandens posistemès nuosėdų nuklidinè sudètis (kiti <1\%) 


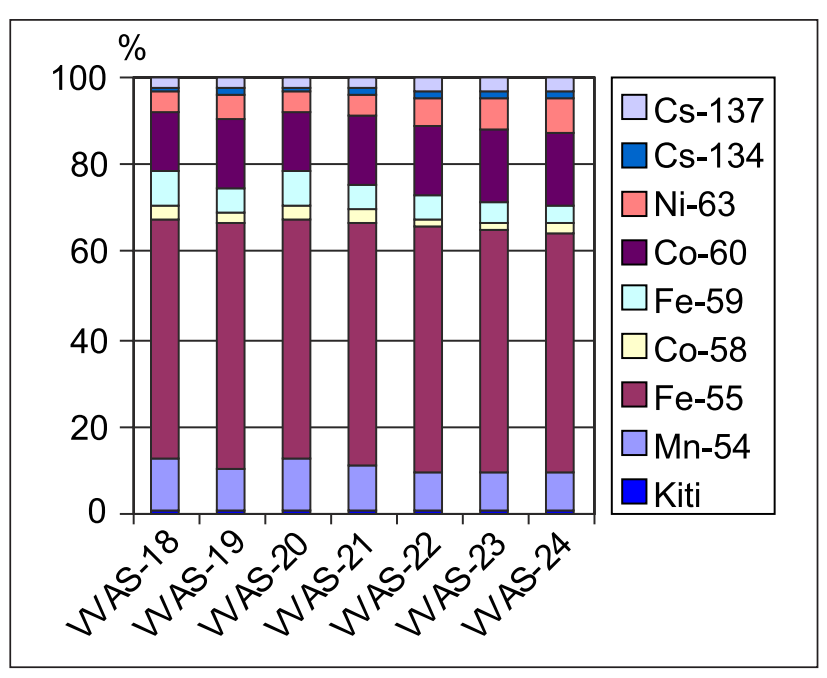

8 pav. VVAS išvalyto vandens posistemès nuosèdų nuklidinè sudètis (kiti $<1 \%)$

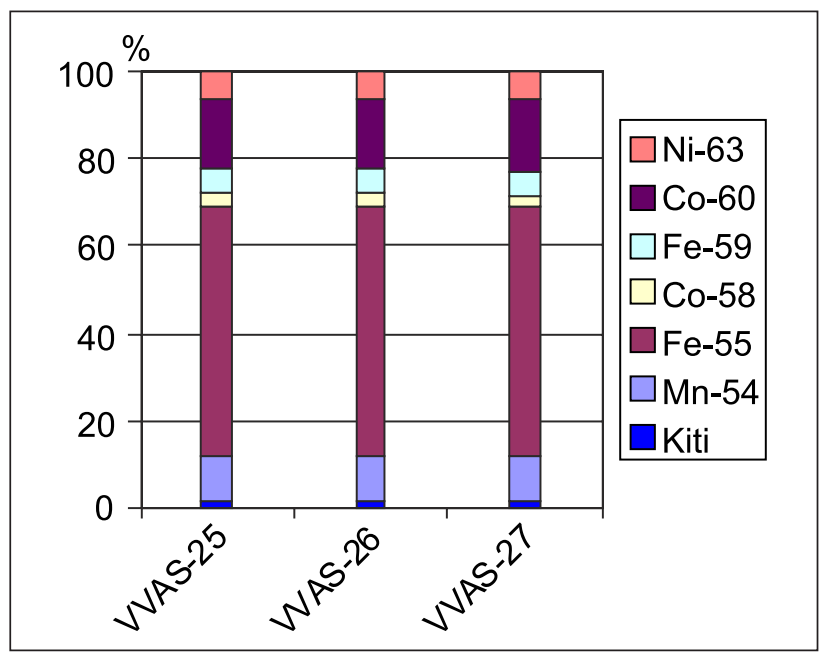

9 pav. VVAS papildomo vandens aušinimo posistemés nuosèdų nuklidinė sudètis (kiti <1\%) dalis. Todèl Cs-134 ir Cs-137 atveju, nors jų koncentracija ir didesnè, pavyzdžiui, už Fe-55 koncentraciją, nuosėdose Fe-55 koncentracija žymiai didesnè nei Cs-134 ar Cs-137. Taip atsitinka dèl to, kad Cs-134, Cs-137 nuklidų tirpumas vandenyje didesnis nei Fe-55.

Laikui bėgant dèl savaiminio skilimo užterštų komponentų (t. y. ant paviršiaus esančių nuosėdų) nuklidinè sudètis kinta. 10-12 pav. pavaizduota kiekvienos VVAS posistemès labiausiai užteršto komponento ant sienučių esančių nuosėdų nuklidinès sudèties kitimas bėgant laikui.

Po tyrinèto 35 metų laikotarpio VVAS komponentų užterštumą labiausiai lemia ilgaamžis nuklidas Ni-63, nes per trumpą laiką suskyla trumpaamžiai nuklidai (Fe-55, Fe-59, Co-58, Co-60, Mn-54). Kitų ilgaamžių nuklidų itaka bendram užterštumui taip pat išauga, nes jų aktyvumas per tokị laiką praktiškai nepakinta.

Skaičiavimai rodo, kad VVAS cirkuliuojančio vandens skleidžiamos dozès galia yra daug mažesnè nei skleidžiama nuosèdų. Galima palyginti apskaičiuotas ir praktiškai išmatuotas dozès galios vertes iš sistemos nepašalinus aušinimo skysčio. Vanduo pašalinamas iš sistemos prieš pradedant išmontavimo darbus.

Radiologiniu požiūriu svarbūs yra nuklidai, lemiantys užterštų komponentų skleidžiamą $\gamma$ spinduliuotę, labai reikšmingas yra Co-60 (13-15 pav.). Komponentų skleidžiamos dozès galia laikui bėgant kinta, taip pat kinta ir didžiausią itaką suminei komponento skleidžiamos dozès galiai turinčių nuklidų pasiskirstymas. Užterštų VVAS komponentų skleidžiamą $\gamma$ spinduliuotę reaktoriaus sustabdymo metu labiausiai lemia Co-60, Fe-59 ir Mn-54, praejus 5 metams po sustabdymo - Co-60. Praejus kelioms dešimtims metų nuo reaktoriaus eksploatavimo nutraukimo, tampa ryški nuklidų Nb-94 ir Cs-137 ịtaka skleidžiamai $\gamma$ spinduliuotei, o Co-60 indèlis į bendrą skleidžiamą $\gamma$ spinduliuotę pamažu mažėja. Nors laikui bėgant

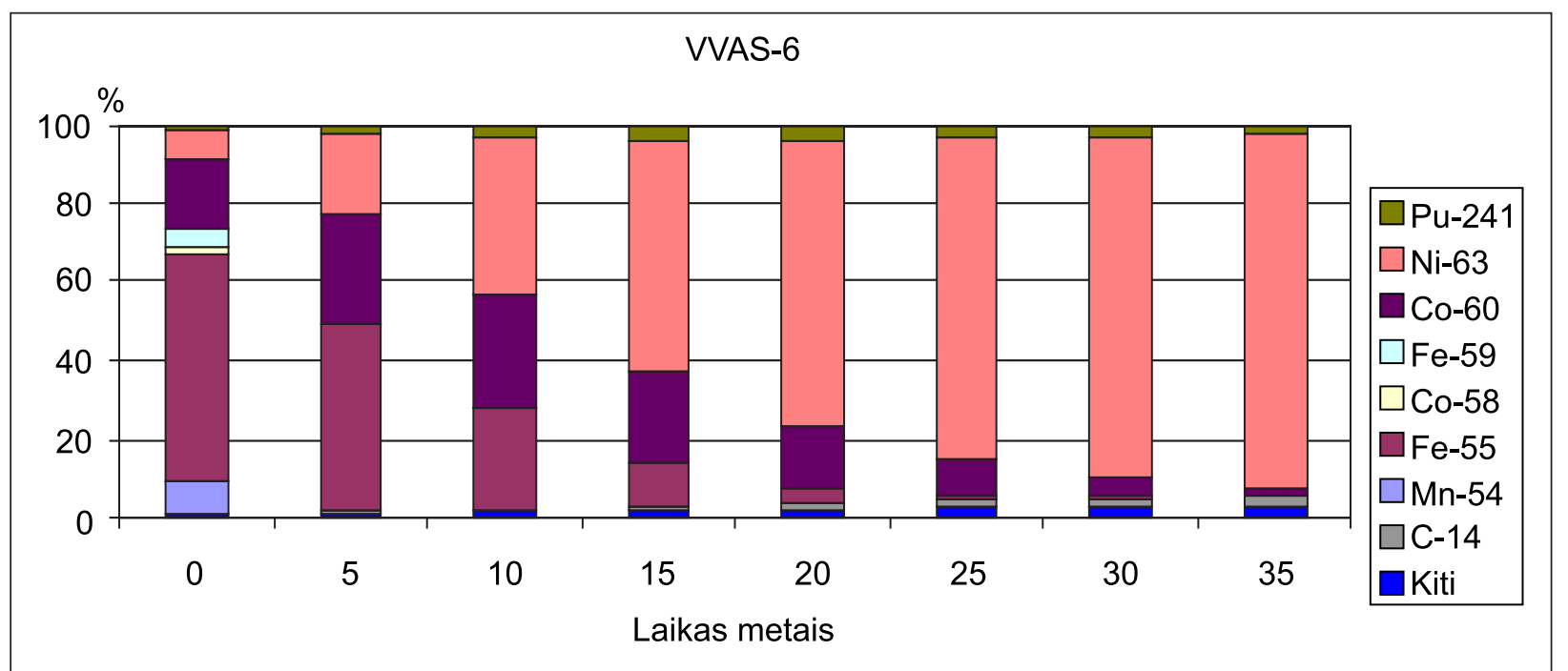

10 pav. Komponento VVAS-6 nuoseddų aktyvumo kitimas bėgant laikui (kiti <1 \%) 


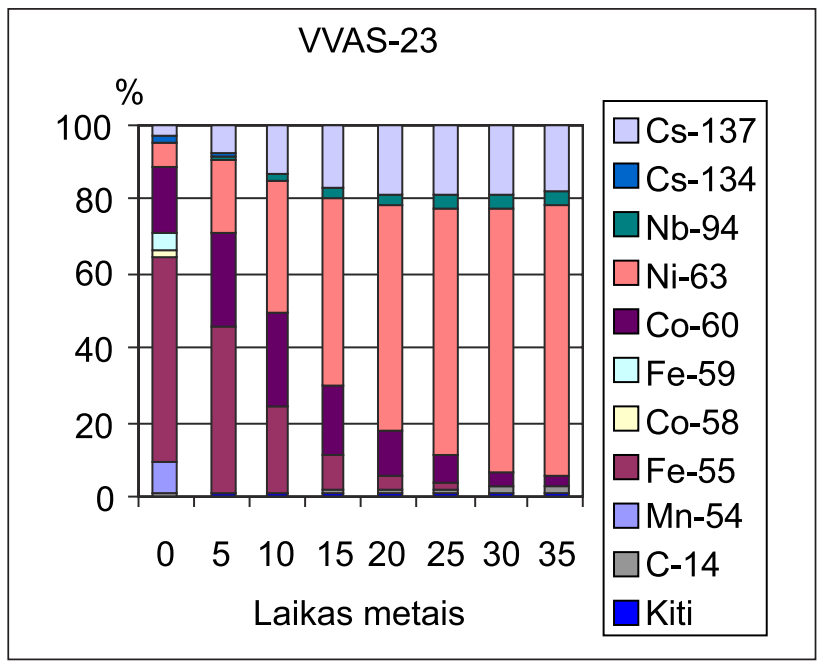

11 pav. Komponento VVAS-23 nuosėdų aktyvumo kitimas bėgant laikui (kiti $<1 \%)$

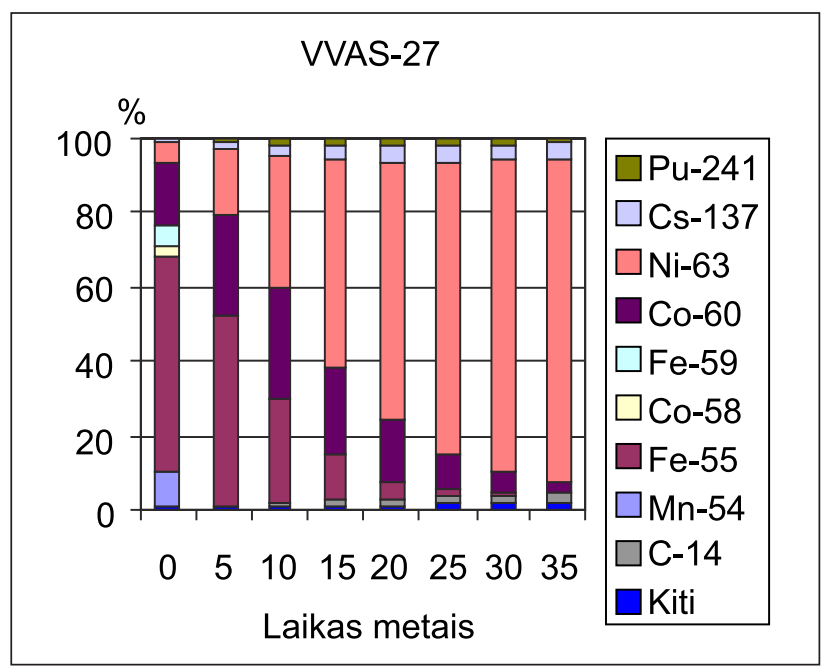

12 pav. Komponento VVAS-27 nuosėdų aktyvumo kitimas bėgant laikui (kiti $<1 \%)$

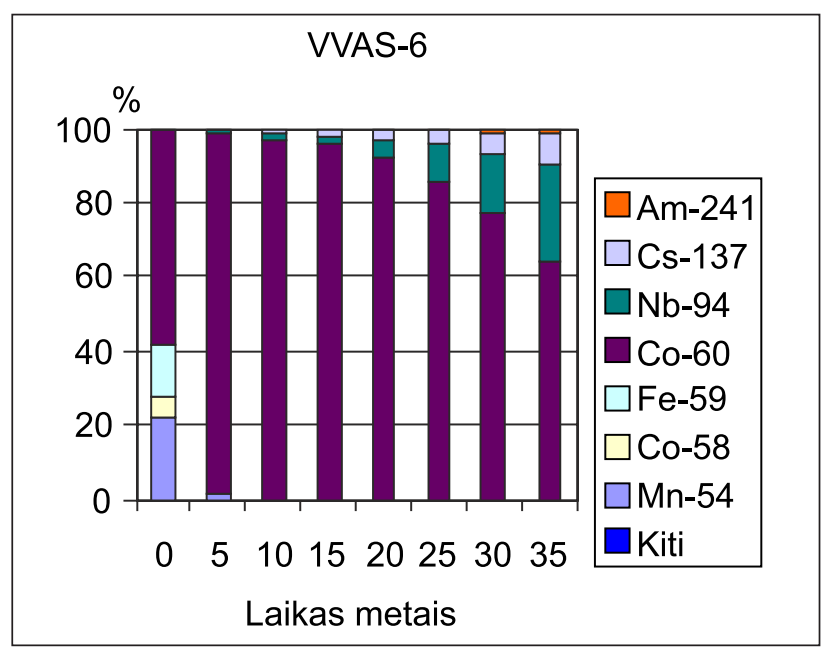

13 pav. Komponento VVAS-6 nuosèdų nuklidų jtakos skleidžiamai suminei dozés galiai kitimas bėgant laikui (kiti $<1 \%$ )

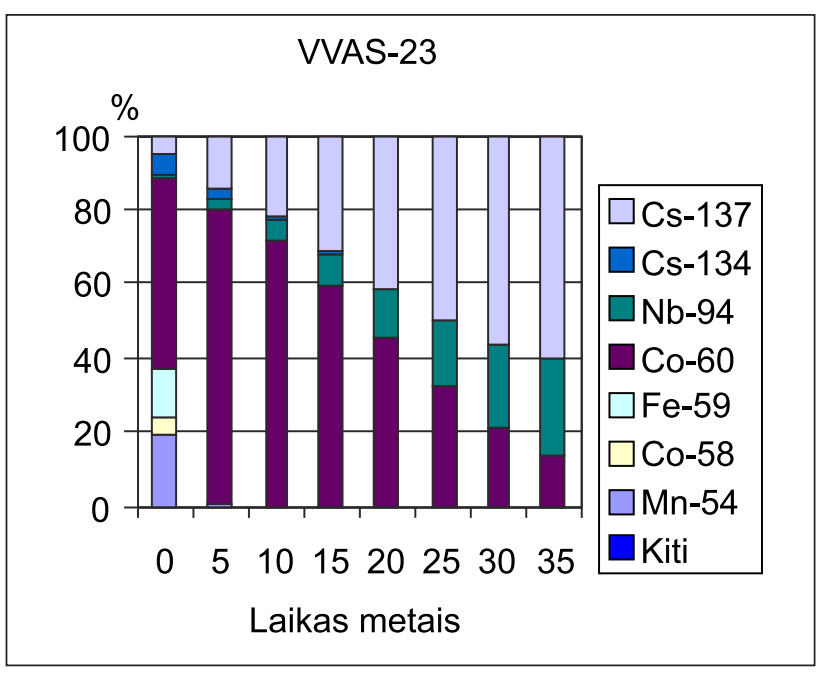

14 pav. Komponento VVAS-23 nuosèdy̨ nuklidų j̇takos skleidžiamai suminei dozés galiai kitimas bègant laikui (kiti <1\%)

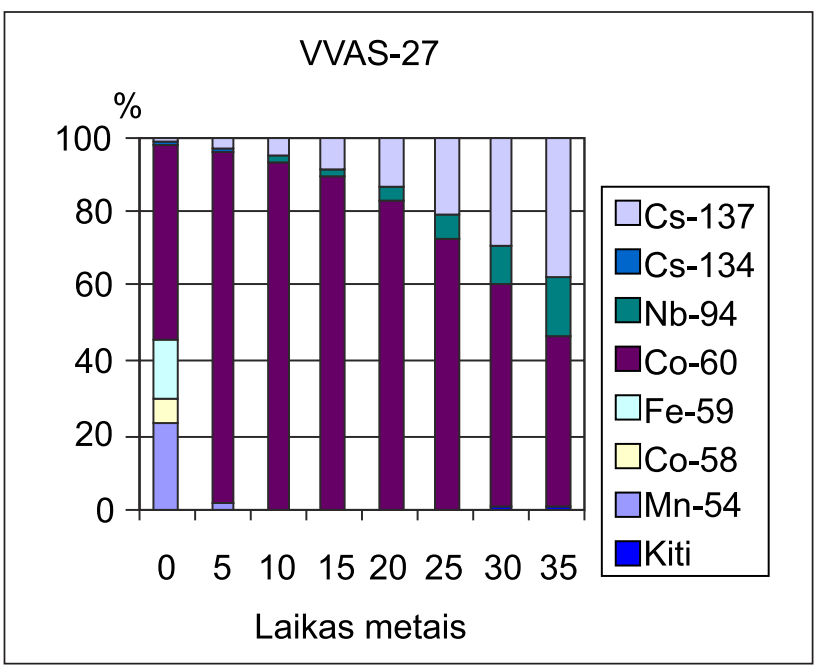

15 pav. Komponento VVAS-27 nuosèdų nuklidų įtakos skleidžiamai suminei dozès galiai kitimas bègant laikui (kiti $<1 \%$ )

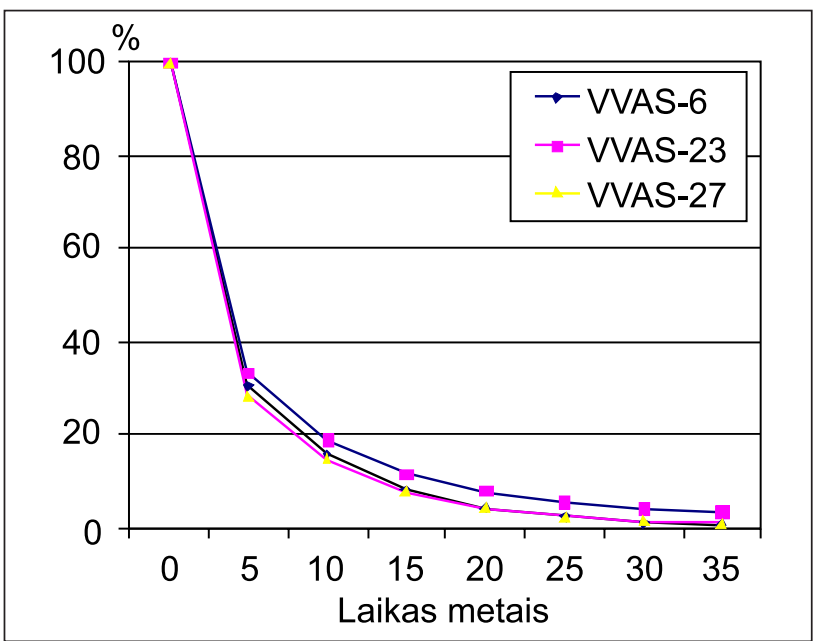

16 pav. Kai kurių VVAS komponentų suminės skleidžiamos dozės galios kitimas bėgant laikui 
Ni-63 nuoseddų aktyvumui turi didžiausią įtaką, tačiau jis yra silpnas $\beta$ - spinduolis ir jo skilimo produktas yra $\mathrm{Cu}-$ 63 nesužadintoje būsenoje. Tokiu būdu Ni-63 skilimas nelydimas $\gamma$ spinduliuotes emisijos, taigi ir kontaktinei dozei jis įtakos praktiškai neturi.

Kaip matyti 16 pav., praèjus 5 metams nuo reaktoriaus galutinio sustabdymo, dozės galia žymiai sumažèja ( 70 \%). Taip atsitinka dèl trumpaamžių nuklidų Fe-55, Co-58, Mn-54 savaiminio skilimo. Kadangi VVAS išmontavimo darbai nebus pradèti iškart po bloko sustabdymo, toks dozès galios sumažèjimas, praèjus 5 metams nuo galutinio 1-ojo bloko sustabdymo, naudingas, nes darbuotojai gaus mažesnes apšvitos dozes. Tai susiję su priimta panaudoto branduolinio kuro tvarkymo strategija, pagal kurią visas panaudotas kuras bus išvežtas, ji išlaikius baseinuose ne mažiau kaip 5 metus.

\section{IŠVADOS}

Atlikus vandens valymo ir aušinimo sistemos (VVAS) komponentų užterštumo radiologinị ịvertinimą bei užterštumo kitimo laikui bėgant analizę, galima daryti šias išvadas:

1. VVAS posistemių bei jų komponentų užterštumas yra labai skirtingas. Nevalyto vandens posistemejje (NV-1) mažiausiai užteršto komponento nuosėdų aktyvumas yra tiktai $1,42 \%$, palyginti su labiausiai užteršto komponento aktyvumu.

2. Išvalyto vandens posistemès (NV-2) labiausiai užteršto ir mažiausiai užteršto komponentų aktyvumas sudaro atitinkamai 28,33 ir $0,86 \%$, palyginti su labiausiai užteršto NV-1 komponento aktyvumu. Tuo tarpu papildomo vandens aušinimo posistemès (NV-3) komponentų aktyvumas tesudaro $1 / 10000$ procento dali, palyginti su labiausiai užteršto NV-1 komponento aktyvumu.

3. Ant VVAS įrangos sienučiu dèl sąlyčio su vandeniu susidariusių nuosèdų nuklidinè sudètis labai skiriasi nuo cirkuliuojančio vandens nuklidinès sudèties. Cs-134 ir Cs137 yra vandenyje dominuojantys nuklidai, o Fe-55, Co-60, Mn-54 - nuosèdose dominuojantys nuklidai.

4. Užterštų VVAS komponentų skleidžiamą $\gamma$ spinduliuotę reaktoriaus sustabdymo metu labiausiai lemia Fe-59 ir Mn-54, o praejus 5 metams nuo jo - Co-60. Praejjus kelioms dešimtims metų nuo reaktoriaus eksploatavimo nutraukimo, tampa ryški nuklidų Nb-94 ir Cs-137 įtaka skleidžiamai $\gamma$ spinduliuotei.

5. Kiekvieno VVAS komponento skleidžiamos suminès dozès galia, praèjus 5 metams nuo reaktoriaus sustabdymo, žymiai sumažèja, todèl tikslinga sistemos išmontavimo darbus pradèti ne anksčiau, kaip praejjus minètam laikotarpiui.

\section{Literatūra}

1. Modelling of Transport of Radioactive Substances in the Primary Circuit of Water-Cooled Reactors. Technical Reports Series No. 1672. Vienna: IAEA, 2012. 149 p.

2. You D., Lambert J., Feron D. Dissolution and solubility of cobalt and nickel ferrites in PWR primary conditions. Proceedings of 7 th International Conference on Water Chemistry of Nuclear Reactors Systems, Bournemouth, 1996.

3. Kritsky V. G. Water Chemistry and Corrosion of NPP Structural Materials. Sinto, 1996.

4. Coolant Technology of Water Cooled Reactors: An Overview. Technical Reports Series No. 347. Vienna: IAEA, 1993.

5. Radiological Characterization of Shut Down Nuclear Reactors for Decommissioning Purposes. Technical Reports Series No. 389. Vienna: IAEA, 1998. 184 p.

6. Almenas K., Kaliatka A., Ušpuras E. Ignalina RBMK1500. A Source Book. Ignalina Safety Analysis Group, 1998. $200 \mathrm{p}$.

7. Lewis B. J., Husain A. Modelling the activity of I129 in the primary coolant of a CANDU reactor. Journal of Nuclear Materials. 2003. Vol. 312. P. 81-96.

8. Beslu P. A computer code PACTOLE to predict activation corrosion products in PWRs. Proceedings of the International Conference on Water Chemistry of Nuclear Reactor Systems, Bournemouth. London: British Nuclear Energy Society, 1978.

9. Lee C. B. Modeling of Corrosion Product Transport in PWR Primary System. Ph. D. Thesis. Massachusetts: Massachusetts Institute of Technology, 1990.

10. Burrill A. K., Menut P. A description of the activity transport computer codes in the IAEA benchmarking exercise. In: Water Chemistry of Nuclear Reactor Systems 8. Bournemouth, UK, 2000. Vol. 1. P. 519-526.

11. Laraia M. Nuclear Decommissioning: Planning, Execution and International Experience (Woodhead Publishing Series in Energy), 2012. 856 p.

12. Lemens B. B., Centner P., Beguin K. Mannaerts. Determination and declaration of critical nuclide inventories in Belgian NPP radwaste streams. Proceedings of WM'99 Conference, February 28 - March 4, 1999. 
Gintautas Poškas, Rimantas Zujus, Gintautas Miliauskas

\section{RADIOLOGICAL CHARACTERIZATION OF THE PURIFICATION AND COOLING SYSTEM OF THE 1st UNIT AT IGNALINA NPP}

Summary

In this article results on radiological characterization of the purification and cooling system (PCS) equipment of the 1st Unit at the Ignalina NPP are presented. The modified program LLWAADECOM (Tractebel Energy Engineering, Belgium) was used for modelling. PCS components and water characteristics, system operation conditions etc. were used as an input for modelling. The data on PCS components' contamination total activity and nuclide vectors at a final reactor shutdown and activity decay and dose rate variation with time for components with the highest contamination were obtained and analyzed.

The analysis showed that contamination of VVAS subsystems and components was not uniform. The most contaminated and least contaminated components' activity of the purified water subsystem is $28.33 \%$ and $0.86 \%$, respectively, compared to the most contaminated component activity of the unpurified water subsystem. The components' activity of the additional water cooling subsystem is negligible.

Key words: Ignalina NPP, purification and cooling system, surface contamination, dose rate
Гинтаутас Пошкас, Римантас Зуюс, Гинтаутас Миляускас

\section{ИССЛЕДОВАНИЕ РАДИОАКТИВНОГО \\ ЗАГРЯЗНЕНИЯ СИСТЕМЫ ОЧИСТКИ И ОХЛАЖДЕНИЯ 1-ГО БЛОКА ИГНАЛИНСКОЙ АЭС}

Резюме

В настоящей работе представлены данные моделирования загрязнённости системы очистки и охлаждения воды (СООВ) 1-го блока Игналинской АЭС. Для моделирования использована модифицирована компьютерная программа LLWAA-DECOM (Tractebel Energy Engineering, Белгия). При моделировании использована информация о характеристиках протекающей воды, условиях работы, характеристиках компонентов системы и т. д. В результате моделирования получены данные об общей активности и нуклидном составе осадков разных компонентов СООВ во время останова реактора, изменение активности осадков во времени, а также изменение мощности дозы для наиболее загрязнённых компонентов.

Установлено, что загрязнение подсистем и компонентов системы СООВ сильно различается. Активность наиболее и наименее загрязняющих компонентов подсистемы очищенной воды составляет 28,33 и 0,86 \% по сравнению с активностью наиболее загрязнённого компонента подсистемы неочищенной воды, а активность компонентов подсистемы дополнительного охлаждения воды незначительна.

Ключевые слова: Игналинская АЭС, система очистки и охлаждения воды, поверхностная загрязнённость, мощность дозы 